\title{
Cellular and metabolic response of hemolymph from engorged Rhipicephalus microplus females exposed to fluazuron
}

\author{
Resposta celular e metabólica da hemolinfa de fêmeas \\ ingurgitadas de Rhipicephalus microplus expostas ao fluazuron
}

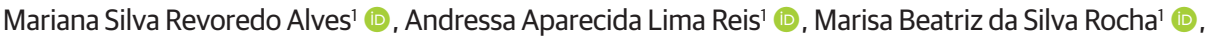 \\ Melina Cardilo Campos Alves² (D), Debora Azevedo Borges ${ }^{1}$ (D), Barbara Rauta de Avelar ${ }^{3 *}$ (D), \\ Diefrey Ribeiro Campos ${ }^{3}$ (D), Yara Peluso Cid ${ }^{4}$ (D) \& Fabio Barbour Scott ${ }^{5}$ (D) \\ 'Veterinarian, MSc., Programa de Pós-Graduação em Ciências Veterinárias (PPGCV), Departamento de Parasitologia Animal \\ (DPA), Instituto de Veterinária (IV), Universidade Federal Rural do Rio de Janeiro (UFRRJ), Seropédica, RJ, Brazil \\ 2Pharmacist, MSc., PPGCV, DPA, IV, UFRRJ, Seropédica, RJ, Brazil \\ ${ }^{3}$ Veterinarian, DSc., PPGCV, DPA, IV, UFRRJ, Seropédica, RJ, Brazil \\ "4Pharmacist. DSc., Departamento de Ciências Farmacêuticas, Instituto de Ciências Biológicas e da Saúde, UFRRJ, Seropédica, \\ RJ, Brazil \\ ${ }^{5}$ Veterinarian, DSc., DPA, IV, UFRRJ, Seropédica, RJ, Brazil.
}

\begin{abstract}
The aim of the present study was to evaluate the hemolymph of engorged females of Rhipicephalus microplus ticks exposed to the growth regulator fluazuron. Firstly, the engorged females were divided into two groups (control and treated) and these were subjected to an immersion test. Hemolymph was collected 24 and 48 hours after the immersion test, to evaluate the cellular and metabolic response. In comparison with the control group, the treated group had lower total hemocyte counts at both times, with lower granulocyte counts and higher spherulocyte counts. There were reductions in glucose and total protein values in both the control and the treated group at the 48-hour evaluation, compared with the 24-hour evaluation. There were no changes in activity levels of lactate dehydrogenase and aspartate aminotransferase enzymes in either group at both times. Fluazuron was not able to promote changes in the energy metabolism of the ticks under the conditions established for this study, but this growth regulator proved to be capable of promoting changes in hemocyte dynamics.
\end{abstract}

Keywords: hemolymph, tick, ectoparasiticide, growth regulator.

\section{Resumo}

O objetivo do presente estudo foi avaliar as alterações na hemolinfa de fêmeas ingurgitadas de carrapatos Rhipicephalus microplus expostas ao regulador de crescimento fluazuron. Primeiramente, as fêmeas ingurgitadas foram divididas em dois grupos (controle e tratado) e estes foram submetidos a um teste de imersão. A hemolinfa foi coletada 24 e 48 horas após o teste de imersão, para avaliação da resposta celular e metabólica. Em comparação com o grupo controle, o grupo tratado apresentou menor contagem de hemócitos totais em ambos os momentos, com menor contagem de granulócitos e maior contagem de esferulócitos. Houve reduções nos valores de glicose e proteína total no grupo controlee no grupo tratado na avaliação de 48 horas, em comparação com a avaliação de 24 horas. Não houve alterações nos níveis de atividade das enzimas lactato desidrogenase e aspartato aminotransferase em nenhum dos grupos em ambos os momentos. O fluazuron não foi capaz de promover alterações no metabolismo energético dos carrapatos nas condições estabelecidas para este estudo, mas esse regulador de crescimento mostrou-se capaz de promover alterações na dinâmica hemocitária.

Palavras-chave: hemolinfa, carrapato, ectoparasiticida, regulador de crescimento.

\section{Introduction}

The tick Rhipicephalus microplus (Ixodida: Ixodidae) is an ectoparasite with cosmopolitan distribution and major importance in relation to livestock. Its parasitism can cause anemia, low meat and milk productivity (Taylor et al., 2015), leather depreciation (Massard \& Fonseca, 2004) and transmission of pathogens like Babesia spp. and Anaplasma marginale (Gonçalves et al., 2011). Economic losses cause by this tick amount to 3.24 billion dollars per year (Grisi et al., 2014).
How to cite: Alves, M. S. R., Reis, A. A. L., Rocha, M. B. S., Alves, M. C. C., Borges, D. A., Avelar, B. R., Campos, D. R., Cid, Y. P., \& Scott, F. B. (2021). Cellular and metabolic response of hemolymph from engorged Rhipicephalus microplus females exposed to fluazuron. Brazilian Journal of Veterinary Medicine, 43, e001821. https://doi. org/10.29374/2527-2179.bjvm001821

Received: June 04, 2021.

Accepted: November 11, 2021.

\section{*Correspondence}

Barbara Rauta de Avelar

Departamento de Parasitologia Animal, Instituto de Veterinária, Universidade Federal Rural do Rio de Janeiro - UFRRJ

Rodovia BR 465, Km 7, Campus Universitário, Zona Rural

CEP 23897-000 - Seropédica (RJ), Brasil

E-mail: barbararauta@gmail.com 
The growth regulator fluazuron belongs to the benzophenylurea group and its mechanism of action consists of inhibition of the formation of chitin through inhibition of enzymes that act in the ecdysis process. It is widely used for controlling $R$. microplus, through inhibiting ecdysis of larvae and nymphs (Maciel et al., 2016). In addition, in adult females, it acts by delaying engorgement, which leads to production of eggs with unviable larvae (Gaudêncio et al., 2017; Ghanim \& Ishaaya, 2011). Tissue changes caused by fluazuron in the cuticle can also occur in the midgut of ticks of the genus Rhipicephalus. (Oliveira et al., 2013).

Changes to hemolymph composition and energy metabolism caused using ectoparasiticides have been studied as a tool for better understanding the physiological changes caused by these compounds in arthropods (Huang et al., 2016).

Growth regulators such as pyriproxyfen and hexaflumuron (Huang et al., 2016; Rahimi et al., 2013) have already been shown to be able to cause changes to hemolymph composition and to the energy and oxidative metabolism of many insects with agricultural importance. Gaudêncio et al. (2016) demonstrated changes to the energy and oxidative metabolism of R. microplus that had been fed on cattle treated with fluazuron. However, few studies have aimed to evaluate the cellular and biochemical alteration of tick hemolymph associated with use of acaricides. Thus, the objective of the present study was to evaluate the energy metabolism and cellular response of the hemolymph of engorged females of $R$. microplus after in vitro exposure to the growth regulator fluazuron.

\section{Materials and methods}

\section{Ticks' origins}

Engorged females of the Porto Alegre strain R. microplus ticks (Canestrini, 1888) were obtained from a laboratory colony that is maintained in stabled cattle. A total of 1440 engorged females, with an average weight of $250 \mathrm{mg}$, were sanitized under running water, dried and placed in Petri dishes.

\section{Preparation of fluazuron dilutions}

Fluazuron (104.7\% - CEVA, Paulínia - BR) emulsifier concentrate (EC) was prepared at a proportion of $5 \%$ in a mixture of $40 \%$ DMSO, $12.5 \%$ acetone, $2 \%$ Triton and $40.5 \%$ N-methyl pyrrolidone. The EC was then directly diluted in water to obtain concentrations of 1000, 500, 50, 25 and $1 \mu \mathrm{g} \cdot \mathrm{mL}^{-1}$ of fluazuron for the adult immersion test (AIT). For evaluation of cellular and metabolic response of the hemolymph, only fluazuron solution at $1000 \mu \mathrm{g} \cdot \mathrm{mL}^{-1}$ was used.

\section{In vitro bioassay}

The AIT was performed in accordance with the recommendations of the Guidelines for Resistance Management and Integrated Parasite Control in Ruminants. The assay was carried out thorough the immersion of 12 engorged females per group at each concentration level $\left(1-1000 \mu \mathrm{g} \cdot \mathrm{mL}^{-1}\right)$ for one minute. Then the solutions were drained and the ticks were dried with absorbent paper, and individually weighed while fixed in the dorsal region. The egg mass was weighted after 21 days, and the hatching percentage was evaluated after 42 days. Reproductive efficiency and effectiveness were calculated according to Drummond et al. (1973).

Six repetitions per group with 60 engorged females each were performed for biochemical evaluations and cellular quantifications of the hemolymph. The engorged females of the treated group were immersed in the diluted aqueous solution for one minute, too. Afterwards, they were dried and kept in a climatized chamber at $27^{\circ} \mathrm{C} \pm 1^{\circ} \mathrm{C}$ and $80 \% \pm 10 \%$ relative humidity (RH). For the control group, the same procedure was performed using the diluent alone.

\section{Hemolymph collection}

Hemolymph was obtained through puncturing the dorsal cuticle of the ticks with a needle (0.3 mm diameter) and collecting into a glass capillary tube (CTechGlass ${ }^{\circledR}$ ) of diameter $0.3 \mathrm{~mm}$ (Angelo et al., 2010). 


\section{Hemocyte quantification}

Cell evaluations were carried out using freshly collected hemolymph. The collected hemolymph $(10 \mu \mathrm{L})$ was used for the total hemocyte count (THC), which was performed with the aid of a light microscopy and Neubauer chamber (New Optics ${ }^{\circledR}$ ). Differential hemocyte count (DHC) was also performed using $10 \mu \mathrm{L}$ of hemolymph. A one-drop smear was made on a glass slide, which was then air dried and fixed in methanol for one minute. Following this, the smear was flushed in 10\% Giemsa solution for approximately 15 minutes and then the material was washed in distilled water to remove excess dye and the slides were deposited on a rack for natural drying.

The DHC was based on the morphology observed under a light microscopy at a magnification of 1000x, by identifying the first 100 cells found on the hemolymph smear glass slide (Silva \& Bittencourt, 2006).

\section{Biochemical evaluations}

To evaluate the biochemical and protein profile, after collection, the hemolymph was stored in a microtube containing $30 \mu \mathrm{L}$ of protease inhibitor cocktail (Inhibit ${ }^{\circledR}$, Sigma-Aldrich) and refrigerated at $4^{\circ} \mathrm{C}$ (Angelo et al., 2010). The hemolymph was assayed without the cellular part, after decanting for $24 \mathrm{~h}$ under refrigeration at $4^{\circ} \mathrm{C}$.

Biochemical evaluations were performed in an automated biochemical analyzer (A-15; Biosystems ${ }^{\circledR}$ ), using kits of the same brand as the equipment. Glucose measurements were made by means of the glucose oxidase/peroxidase and total protein (TP) method, through the biuret method. The enzymatic activity of aspartate aminotransferase (AST) was ascertained using the reference method proposed by the International Federation of Clinical Chemistry and Laboratory Medicine without pyridoxal phosphate. Lactate dehydrogenase (LDH) was assayed using the pyruvate method.

\section{Statistical analysis}

Statistical analysis was performed using the Bioestat 5.0 software. Data from the AIT assay were evaluated for distribution using the D'Agostino-Pearson test. The analysis of means was performed by Anova for data with normal distribution and the Kruskal-Wallis test for nonparametric data. Hemocytes quantification and biochemical evaluations data were evaluated with regard to normal distribution using the Shapiro-Wilk test. The means of the parameters evaluated in the control and treated groups were compared using the T test with a 95\% confidence interval $(p<0.05)$.

\section{Results}

The results of the AIT with fluazuron solutions in the evaluated concentration range (1-1000 $\left.\mu \mathrm{g} \cdot \mathrm{mL}^{-1}\right)$ are described in Table 1. Regarding the total hemocyte count, in comparison with the control group, the treated group showed reductions in the THC at both evaluation times. Also, both the control and the treated group showed a reduction in the THC at 48h, compared with 24h (Table 2).

In this study, the DHC showed that four cell types were present: prohemocytes, plasmatocytes, granulocytes and spherulocytes (Figure1). The relative counts of prohemocytes and plasmatocytes did not change after treatment, at the evaluations of 24 and $48 \mathrm{~h}$. On the other hand, for the treated group, there was a decrease in the number of granulocytes at the $48 \mathrm{~h}$ evaluation and an increase in the number of spherulocytes at both evaluation times. The average values are presented in Table 2 .

Regarding the biochemical parameters (glucose, AST, LDH and TP), reductions were observed over the analysis times, from $24 \mathrm{~h}$ to $48 \mathrm{~h}$, and these occurred both in the control group and in the group treated with fluazuron. In comparing the two groups, it was seen that there was no significant difference in relation to the treatment, at either of the two analysis times (Table 3). 
Table 1. Mean values engorged female, egg mass, hatching percentage and reproductive efficiency. And efficacy about reproductive efficiency of engorged female Rhipicephalus microplus exposed to fluazuron.

\begin{tabular}{|c|c|c|c|c|c|}
\hline $\begin{array}{l}\text { Concentration } \\
\qquad\left(\mu \mathrm{g} \cdot \mathrm{mL}^{-1}\right)\end{array}$ & $\begin{array}{l}\text { Engorged } \\
\text { Female } \\
\text { before } \\
\text { oviposition } \\
\text { (g) }\end{array}$ & $\begin{array}{l}\text { Egg mass } \\
\text { weight (g) }\end{array}$ & $\begin{array}{c}\text { Hatching } \\
\text { percentage } \\
(\%)\end{array}$ & $\begin{array}{l}\text { Reproductive } \\
\text { efficiency }\end{array}$ & $\begin{array}{c}\text { Efficacy } \\
\text { about } \\
\text { Reproductive } \\
\text { efficiency (\%) }\end{array}$ \\
\hline Control & $\begin{array}{c}0.289 \\
\pm \\
0.044^{\mathrm{a}}\end{array}$ & $\begin{array}{c}0.142 \\
\pm \\
0.025^{\mathrm{a}}\end{array}$ & $\begin{array}{c}80.75 \\
\pm \\
9.909^{a}\end{array}$ & $\begin{array}{c}793730.9 \\
\pm \\
115739.5^{a}\end{array}$ & \\
\hline 1 & $\begin{array}{c}0.262 \\
\pm \\
0.040^{\mathrm{a}}\end{array}$ & $\begin{array}{c}0.127 \\
\pm \\
0.018^{\mathrm{a}}\end{array}$ & $\begin{array}{c}80.25 \\
\pm \\
10.457^{\mathrm{a}}\end{array}$ & $\begin{array}{c}786984.8 \\
\pm \\
141014.2^{\mathrm{a}}\end{array}$ & 0.8 \\
\hline 25 & $\begin{array}{c}0.254 \\
\pm \\
0.023^{\mathrm{a}}\end{array}$ & $\begin{array}{c}0.135 \\
\pm \\
0.019^{a}\end{array}$ & $\begin{array}{c}26.92 \\
\pm \\
23.067^{b}\end{array}$ & $\begin{array}{c}295933.8 \\
\pm \\
258839.5^{b}\end{array}$ & 62.7 \\
\hline 50 & $\begin{array}{c}0.244 \\
\pm \\
0.024^{\mathrm{a}}\end{array}$ & $\begin{array}{c}0.111 \\
\pm \\
0.032^{\mathrm{a}}\end{array}$ & $\begin{array}{c}13.17 \\
\pm \\
19.705^{b}\end{array}$ & $\begin{array}{c}131704.9 \\
\pm \\
198455.1^{\mathrm{b}}\end{array}$ & 83.4 \\
\hline 500 & $\begin{array}{c}0.246 \\
\pm \\
0.022^{\mathrm{a}}\end{array}$ & $\begin{array}{c}0.114 \\
\pm \\
0.033^{\mathrm{a}}\end{array}$ & $\begin{array}{c}1.92 \\
\pm \\
6.357^{\mathrm{b}}\end{array}$ & $\begin{array}{c}19089.07 \\
\pm \\
63311.3^{b}\end{array}$ & 97.6 \\
\hline 1000 & $\begin{array}{c}0.282 \\
\pm \\
0.038^{\mathrm{a}}\end{array}$ & $\begin{array}{c}0.142 \\
\pm \\
0.021^{\mathrm{a}}\end{array}$ & $\begin{array}{c}0.00 \\
\pm \\
0.000^{\mathrm{b}}\end{array}$ & $\begin{array}{c}0 \\
\pm \\
0.0^{\mathrm{b}}\end{array}$ & 100.0 \\
\hline
\end{tabular}

Table 2. Mean values of total hemocyte count and differential hemocyte count in the hemolymph of engorged females of Rhipicephalus microplus, 24 and 48 hours after exposure to fluazuron.

\begin{tabular}{|c|c|c|c|c|c|c|}
\hline \multirow{2}{*}{ Parameter } & \multicolumn{3}{|c|}{24 hours } & \multicolumn{3}{|c|}{48 hours } \\
\hline & Control & Treated & p-value & Control & Treated & p-value \\
\hline THCs $\left(x 10^{3} / \mu \mathrm{l}\right)$ & 8.75 & 4.86 & 0.0001 & 3.49 & 2.03 & 0.0002 \\
\hline Prohemocyte (\%) & 4 & 3 & 0.7882 & 3 & 2 & 0.5095 \\
\hline Granulocytes (\%) & 75 & 61 & 0.0084 & 64 & 46 & 0.0163 \\
\hline $\begin{array}{c}\text { Plasmatocytes } \\
\text { (\%) }\end{array}$ & 4 & 4 & 0.8768 & 4 & 5 & 0.7938 \\
\hline $\begin{array}{c}\text { Spherulocytes } \\
\text { (\%) }\end{array}$ & 18 & 32 & 0.0021 & 29 & 47 & 0.0208 \\
\hline
\end{tabular}

THCs = Total hemocyte counts.

Table 3. Mean values of aspartate aminotransferase, glucose, lactate dehydrogenase and total protein in the hemolymph of engorged females of Rhipicephalus microplus, 24 and 48 hours after exposure to fluazuron.

\begin{tabular}{|c|c|c|c|c|c|c|}
\hline \multirow{2}{*}{$\begin{array}{c}\text { Biochemical } \\
\text { parameter }\end{array}$} & \multicolumn{3}{|c|}{24 hours } & \multicolumn{3}{|c|}{48 hours } \\
\hline & Control & Treated & $p$-value & Control & Treated & p-value \\
\hline AST (U/L) & 131.5 & 118.2 & 0.5354 & 126.8 & 102.7 & 0.077 \\
\hline Glucose (mg/dL) & 58.0 & 55.3 & 0.6511 & 42.0 & 40.8 & 0.7214 \\
\hline $\mathrm{LDH}(\mathrm{U} / \mathrm{L})$ & 289.5 & 298.8 & 0.8887 & 143.8 & 155.7 & 0.6358 \\
\hline Total protein (g/L) & 5.5 & 5.2 & 0.9955 & 4.6 & 4.4 & 0.2963 \\
\hline
\end{tabular}

AST = aspartate aminotransferase; LDH = lactate dehydrogenase. 


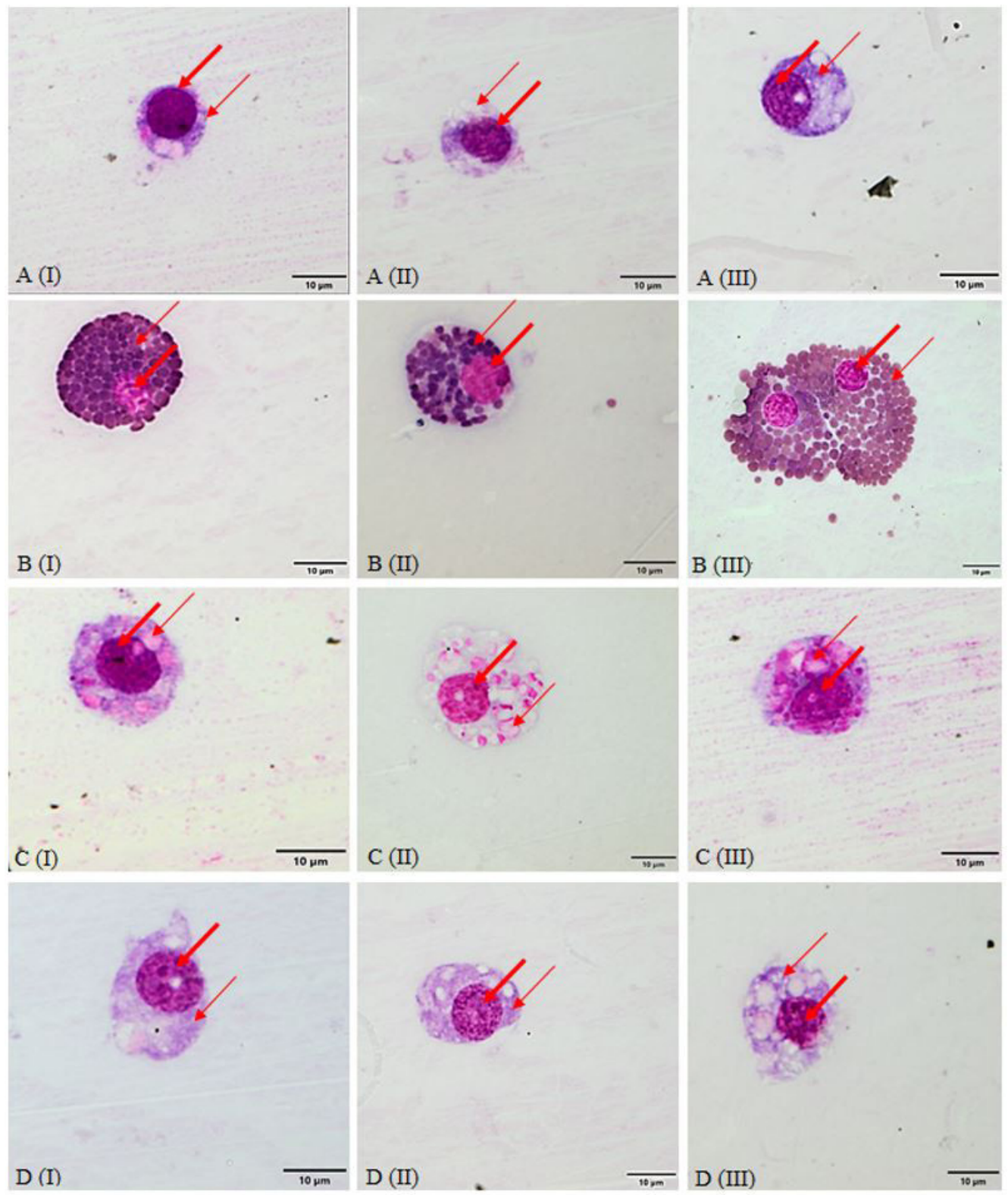

Figure 1. Hemocytes identified in hemolymph of engorged females of Rhipicephalus microplus. (A) Prohemocyte. Large nucleus (thick red arrow) and scarce cytoplasm with fine granulations and occasional vacuoles (thin red arrow); (B) Granulocyte. Eccentric core (thick red arrow) and granules covering the cytoplasm (thin red arrow); (C) Spherulocyte. Eccentric nucleus (thick red arrow) and cytoplasm presenting spherical and rare vacuoles (thin red arrow); (D) Plasmatocyte. Rounded core (thick red arrow) and cytoplasm with small vacuoles and granulations (thin red arrow). Light microscopy (magnification 1000x). Giemsa staining.

\section{Discussion}

The effectiveness on the reproductive efficiency observed in the AIT was 97.6\% at concentrations of $500 \mu \mathrm{g} \cdot \mathrm{mL}^{-1}$, reaching $100 \%$ at $1000 \mu \mathrm{g} \cdot \mathrm{mL}^{-1}$. Fluazuron in vitro interfered only in egg hatching, corroborating Fao (2004), with no statistical differences observed between the postures of the control and treated groups.

Works evaluating the cellular response of the hemolymph of $R$. microplus have basically examined fungal infections, like the study with Metarhizium robertsii conducted by Fiorotti et al. (2019). Few studies have evaluated the action of ectoparasiticides in the dynamics of tick hemocytes. In the present study, reductions in THC in ticks exposed to fluazuron $1000 \mu \mathrm{g} \cdot \mathrm{mL}^{-1}$ were observed 
at $24 \mathrm{~h}(p<0.0001)$ and $48 \mathrm{~h}(p<0.0002)$, based on results of the AIT. This reduction in THC was also observed after 72 hours of exposure of the fourth-stage larva of Spodoptera littoralis (Lepdoptera: Noctuidae) to other regulators of chitin synthesis such as lufenuron and chlorfluazuron (Abou-Taleb et al., 2015). Similarly, THC was reduced in Mytbimna separata (Lepdoptera: Noctuidae) larvae when exposed to the hexaflumuron growth regulator (Huang et al., 2016). This negative effect on THC can be attributed to a possible cytotoxic effect or to inhibition of hematopoietic function (Zibaee et al., 2012; Zhu et al., 2012).

The DHC showed that there was a significant reduction in the relative count of granulocytes in $24 \mathrm{~h}(p<0.0084)$ and $48 \mathrm{~h}(p<0.0163)$ evaluations. This result was similar to what was demonstrated by Abou-Taleb et al. (2015), who showed that there were reductions in granulocyte and plasmatocyte counts in insects (S. littoralis) exposed to lufenuron and chlorfluazuron. Similar results were also described by Rahimi et al. (2013), who showed that pyriproxyfen and hexaflumuron can reduce the granulocyte count of Ephestia kuehniella (Lepdoptera: Pyralidae) after 24 hours of exposure. The reduction in phagocytic cells may lead to reduction of the immunity mediated by arthropod cells, thus making them more susceptible to infection (Zibaee et al., 2012).

Another important change in the DHC was a significant increase in the relative spherulocyte count in $24 \mathrm{~h}(p<0.0021)$ and $48 \mathrm{~h}(p<0.0208)$ evaluations. Increased presence of this cell type was also described by Abou-Taleb et al. (2015) in larvae of $S$. littoralis treated with lufenuron and chlorfluazuron. However, this alteration was not observed in other insects exposed to pyriproxyfen and hexaflumuron (Huang et al., 2016; Rahimi et al., 2013]. Increased presence of this cell type indicates a high rate of renewal, which suggests that it may be related to asset detoxification, as suggested by Arnold and Hinks (Arnold \& Hinks, 1976).

The reduction in hemolymph glucose concentration occurred in the control and treated groups at both evaluation times. Moraes et al. (2007) observed that this reduction could be explained by consumption of this carbohydrate during embryogenesis. Gaudêncio et al. (2016) also observed that the reduction in this carbohydrate occurred in engorged females fed on cattle, whether or not these had been treated with fluazuron.

The reductions in $\mathrm{LDH}$ concentrations at the $24 \mathrm{~h}$ and $48 \mathrm{~h}$ evaluations may indicate that a decrease in energy metabolism was occurring through oxidative pathways, with consequent adaptation to anaerobic metabolism as a compensatory measure for maintaining energy reserves (Tunholi-Alves et al., 2014).

The AST activity levels were similar in the control and treated groups at both evaluation times. Similar results were observed by Gaudêncio et al. (2016) in engorged females collected from cattle that had been treated with fluazuron. The increase in the levels of this enzyme occurs due to the gluconeogenesis process during amino acid catabolism, which is accentuated during embryogenesis or cytological lesion and cell extravasation (Angelo et al., 2015).

Reductions in TP concentration occurred both in the control group and in the treated group, at both evaluation times ( 24 and $48 \mathrm{~h}$ ). According to Seixas et al. (2010) reductions in TP concentration can be expected as a consequence of the pre-laying period, with TP consumption for egg formation and maturation.

The biochemical changes observed in the present study are most likely related to physiological adaptations of the engorged female to the embryogenesis process and to egg laying. It is unlikely that these changes had any relationship with fluazuron treatment. However, it could be seen that fluazuron caused important changes in the THC, with a reduction in the relative number of granulocytes and an increase in the number of spherulocytes. These changes show that fluazuron may be able to impair the cellular immune response of arthropods.

\section{Conclusion}

Based on the results obtained in this study, it is possible to conclude that fluazuron was not able to cause changes to the energy metabolism of R. microplus. However, it promoted changes in the dynamics of hemocytes in these ticks. 


\section{Acknowledgements}

The authors thank for Jéssica Fiorotti de Paulo the support provided throughout the study. The work was carried out at Laboratório de Quimioterapia Experimental em Parasitologia Veterinária/ Departamento de Parasitologia Animal do Instituto de Veterinária da Universidade Federal Rural Do Rio De Janeiro, Seropédica, RJ, Brazil.

\section{Ethics statement}

The ticks were obtained from a laboratory colony that is maintained in cattle in Laboratório de Quimioterapia Experimental em Parasitologia Veterinária and approved by the ethics committee for animal use of "institution name hidden for review" under the protocol number 092/2014.

\section{Financial support}

DAB, MBSR and FBS - Received scholarship from CNPq (Conselho Nacional de Desenvolvimento Científico e Tecnológico). AALR and MCCA - Received scholarship from CAPES (Coordenação de Aperfeiçoamento de Pessoal de Nível Superior). MRSA, BRA, DRC and FBS - Received scholarship from FAPUR (Fundação de Apoio à Pesquisa Científica e Tecnológica da UFRRJ). YPC - None.

\section{Conflict of interests}

MRSA, AALR, MBSR, MCCA<DAB, BRA, DRC, YPC, FBS no conflicts of interest.

\section{Authors' contributions}

MRSA, AALR, MBSR, MCCA, DAB and BRA - Development of methodology; preparation and writing the initial draft. DRC - Application of statistical study data, Review and Editing manuscript. YPC - Writing, Review and Editing manuscript. FBS - Review and Editing manuscript, Acquisition of the financial support for the project leading to this publication.

\section{Availability of complementary results}

The study was carried out at - UFRRJ, Seropédica, RJ, Brazil

\section{References}

Abou-Taleb, H. K., Zahran, H. E. M., \& Gad, A. A. (2015). Biochemical and physiological effects of lufenuron and chlorfluazuron on Spodoptera littoralis (Boisd.)(Lepidoptera: Noctuidae). Journal of Entomology, 12(2), 77-86. http://dx.doi.org/10.3923/je.2015.77.86.

Angelo, I. C., Gôlo, P. S., Camargo, M. G., Kluck, G. E. G., Folly, E., \& Bittencourt, V. R. E. P. (2010). Haemolymph protein and lipid profile of Rhipicephalus (Boophilus) microplus infected by fungi. Transboundary and Emerging Diseases, 57(1-2), 79-83. http://dx.doi.org/10.1111/j.1865-1682.2010.01119.x. PMid:20537114.

Angelo, I. C., Tunholi-Alves, V. M., Tunholi, V. M., Perinotto, W. M., Gôlo, P. S., Camargo, M. G., Quinelato, S., Pinheiro, J., \& Bittencourt, V. R. (2015). Physiological changes in Rhipicephalus microplus (Acari: Ixodidae) experimentally infected with entomopathogenic fungi. Parasitology Research, 114(1), 219-225. http://dx.doi. org/10.1007/s00436-014-4181-5. PMid:25346195.

Arnold, J. W., \& Hinks, C. F. (1976). Haemopoiesis in Lepidoptera. I. The multiplication of circulating haemocytes. Canadian Journal of Zoology, 54(6), 1003-1012. http://dx.doi.org/10.1139/z76-112.

Drummond, R. E. A., Ernst, S. E., Trevino, J. L., Gladney, W. J., \& Graham, O. H. (1973). Boophilus annulatus and $B$. microplus: laboratory tests of insecticides. Journal of economic entomology, 66(1), 130-133.

FAO (Food and Agriculture Organization), 2004. Resistance Management and Integrated Parasite Control in Ruminants - Guidelines, Module 1 - Ticks: Acaricide Resistance: Diagnosis, Management and Prevention. Food and Agriculture Organization, Animal Production and Health Division, Rome, pp. 25-77.

Fiorotti, J., Menna-Barreto, R. F. S., Gôlo, P. S., Coutinho-Rodrigues, C. J. B., Bitencourt, R. O. B., Spadacci-Morena, D. D., Angelo, I. D. C., \& Bittencourt, V. R. E. P. (2019). Ultrastructural and cytotoxic effects of Metarhizium robertsii infection on Rhipicephalus microplus hemocytes. Frontiers in Physiology, 10, 654. http://dx.doi. org/10.3389/fphys.2019.00654. PMid:31191351.

Gaudêncio, F. N., Klafke, G. M., Tunholi-Alves, V. M., Ferreira, T. P., Coelho, C. N., da Fonseca, A. H., da Costa Angelo, I., \& Pinheiro, J. (2017). Activity of carboxylesterases, glutathione-S-transferase and monooxygenase on Rhipicephalus microplus exposed to fluazuron. Parasitology International, 66(5), 584-587. http://dx.doi. org/10.1016/j.parint.2017.04.006. PMid:28435029. 
Gaudêncio, F. N., Tunholi-Alves, V. M., Lima, M. G., Gôlo, P. S., Angelo, I. D. C., Castro, R. N., \& Pinheiro, J. (2016). Alterações no metabolismo oxidativo de carrapatos Rhipicephalus (Boophilus) microplus em resposta à exposição ao regulador de crescimento fluazuron. Revista Brasileira de Parasitologia Veterinária, 25(1), 54-60. http://dx.doi.org/10.1590/S1984-29612016006. PMid:26982563.

Ghanim, M., \& Ishaaya, I. (2010). Insecticides with novel modes of action: mechanism and resistance management. In I. Ishaaya \& D. Degheele (Eds.), Insecticides with novel modes of action: mechanism and application (pp. 385-407). Berlin: Springer.

Gonçalves, R. C., da Silva, A. A., Ferreira, D. O. L., Chiacchio, S. B., Lopes, R. S., Borges, A. S., \& Amorim, R. M. (2011). Tick fever in cattle in the region of Botucatu-SP: a retrospective study of 1986-2007. Semina: Ciências Agrárias, 32(1), 307-312. http://dx.doi.org/10.5433/1679-0359.2011v32n1p307.

Grisi, L., Leite, R. C., Martins, J. R. S., Barros, A. T. M., Andreotti, R., Cançado, P. H. D., León, A. A. P., Pereira, J. B., \& Villela, H. S. (2014). Reassessment of the potential economic impact of cattle parasites in Brazil. Revista Brasileira de Parasitologia Veterinária, 23(2), 150-156. http://dx.doi.org/10.1590/S1984-29612014042. PMid:25054492.

Huang, Q., Zhang, L., Yang, C., Yun, X., \& He, Y. (2016). The competence of hemocyte immunity in the armyworm Mythimna separata larvae to sublethal hexaflumuron exposure. Pesticide Biochemistry and Physiology, 130, 31-38. http://dx.doi.org/10.1016/j.pestbp.2015.12.003. PMid:27155481.

Maciel, W. G., Lopes, W. D. Z., Gomes, L. V. C., Cruz, B. C., Felippelli, G., Santos, I. B. D., Borges, F. A., Gonçalves, W. A., Scarpa, A. B., Nicaretta, J. E., Bastos, T. S. A., \& Costa, A. J. (2016). Susceptibility of Rhipicephalus (Boophilus) microplus to fluazuron (2.5 mg/kg) and a combination of novaluron $(2.0 \mathrm{mg} / \mathrm{kg})+$ eprinomectin (0.36 mg/kg) in field studies in Brazil. Preventive Veterinary Medicine, 135, 74-86. http://dx.doi.org/10.1016/j. prevetmed.2016.10.019. PMid:27931932.

Massard, C. L., \& Fonseca, A. H. (2004). Carrapatos e doenças transmitidas, comuns ao homem e aos animais. A Hora Veterinária, 135(1), 15-23.

Moraes, J., Galina, A., Alvarenga, P. H., Rezende, G. L., Masuda, A., Vaz Junior, I.S., \& Logullo, C. (2007). Glucose metabolism during embryogenesis of the hard tick Boophilus microplus. Comparative Biochemistry and Physiology. Part A, Molecular \& Integrative Physiology, 146(4), 528-533. http://dx.doi.org/10.1016/j.cbpa.2006.05.009. PMid:16904922.

Oliveira, P. R., Calligaris, I. B., Roma, G. C., Bechara, G. H., \& Camargo-Mathias, M. I. (2013). Fluazuron-induced morphophysiological changes in the cuticle formation and midgut of Rhipicephalus sanguineus Latreille, 1806 (Acari: Ixodidae) nymphs. Parasitology Research, 112(1), 45-58. http://dx.doi.org/10.1007/s00436-0123103-7. PMid:22992894.

Rahimi, V., Zibaee, A., Mojahed, S., Maddahi, K., \& Zare, D. (2013). Effects of pyriproxyfen and hexaflumuron on cellular immunity of Ephestia kuebniella Zeller (Lepidoptera: Pyralidae). Romanian Journal of BiologyZoology, 58(2), 151-162.

Seixas, A., Oldiges, D. P., Vaz Junior, I. S., \& Termignoni, C. (2010). Endocrinologia e controle da vitelogênese em carrapatos. Acta Scientiae Veterinariae, 38(2), 95-111. http://dx.doi.org/10.22456/1679-9216.16586.

Silva, S. B., \& Bittencourt, V. R. E. (2006). Avaliação da resposta celular de fêmeas ingurgitadas de Boophilus microplus (CANESTRINI, 1887) inoculadas com Metarbizium anisopliae, Beauveria bassiana, Penicillium corylophilum ou Fusarium oxysporum. Revista Brasileira de Parasitologia Veterinária, 15(4), 151-156. PMid:17196118.

Taylor, M. A., Coop, R. L., \& Wall, R. L. (2015). Veterinary parasitology. Chichester: John Wiley \& Sons. http://dx.doi. org/10.1002/9781119073680.

Tunholi-Alves, V. M., Tunholi, V. M., Castro, R. N., Sant'Ana, L. D., Santos-Amaral, L., de Oliveira, A. P., Garcia, J., Thiengo, S. C., Pinheiro, J., \& Maldonado Junior, A. (2014). Activation of anaerobic metabolism in Biomphalaria glabrata (Mollusca: Gastropoda) experimentally infected by Angiostrongylus cantonensis (Nematoda, Metastrongylidae) by high-performance liquid chromatography. Parasitology International, 63(1), 64-68. http://dx.doi.org/10.1016/j.parint.2013.09.004. PMid:24042059.

Zhu, Q., He, Y., Yao, J., Liu, Y., Tao, L., \& Huang, Q. (2012). Effects of sublethal concentrations of the chitin synthesis inhibitor, hexaflumuron, on the development and hemolymph physiology of the cutworm, Spodoptera litura. Journal of Insect Science, 12(1), 27. http://dx.doi.org/10.1673/031.012.2701. PMid:22958164.

Zibaee, A., Bandani, A. R., \& Malagoli, D. (2012). Methoxyfenozide and pyriproxifen alter the cellular immune reactions of Eurygaster integriceps Puton (Hemiptera: Scutelleridae) against Beauveria bassiana. Pesticide Biochemistry and Physiology, 102(1), 30-37. http://dx.doi.org/10.1016/j.pestbp.2011.10.006. 